\title{
Incretin secretion stimulated by ursodeoxycholic acid in healthy subjects
}

\author{
Masanori Murakami ${ }^{1}$, Naoko Une ${ }^{1}$, Maiko Nishizawa' ${ }^{1}$ Sayaka Suzuki ${ }^{1}$, Hideki Ito ${ }^{2}$ and Toshiyuki Horiuchi ${ }^{*}$
}

\begin{abstract}
Bile acids play an important role in post-prandial glucose metabolism by stimulating release of glucagon-like peptide-1 (GLP-1) via the G-protein-coupled receptor TGR5, which is expressed in intestinal L cells. Thus, bile acid sequestrants are expected to stimulate secretion of endogenous GLP-1 through TGR5. We investigated incretin and insulin secretion after a meal with and without ursodeoxycholic acid (UDCA), a widely used therapeutic agent in liver diseases, in 7 non-diabetic Japanese subjects. We found that UDCA intake resulted in higher GLP-1 secretion (area under the curve [AUC] of 0-60 min after meal without UDCA, $450 \pm 162 \mathrm{mmol} \cdot \mathrm{min} / \mathrm{l}$; with UDCA, $649 \pm$ $232 \mathrm{mmol} \cdot \mathrm{min} / \mathrm{l}, P=0.046$ ) and lower blood glucose (AUC of 0-60 min without UDCA, $7191 \pm 250 \mathrm{mg} \cdot \mathrm{min} / \mathrm{dl}$; with UDCA, $6716 \pm 189 \mathrm{mg} \cdot \mathrm{min} / \mathrm{dl}, P=0.001)$, although we did not find statistically significant insulin increase by UDCA intake (AUC of 0-60 min without UDCA, $1551 \pm 418 \mu \mathrm{U} \cdot \mathrm{min} / \mathrm{ml}$; with UDCA, $1941 \pm 246 \mu \mathrm{U} \cdot \mathrm{min} / \mathrm{ml}, P=0.065$ ). These results suggest that UDCA increases bile-induced GLP-1 secretion. Ours is the first report showing increased GLP-1 secretion and decreased blood glucose in response to UDCA.
\end{abstract}

Keywords: Bile acid, Ursodeoxycholic acid, Glucagon-like peptide-1

\section{Background}

Glucagon-like peptide-1 (GLP-1) is major incretins released from gut endocrine cells in response to nutrient ingestion. Notably, GLP-1 not only stimulates insulin biosynthesis and secretion and promotes beta cell proliferation, but also inhibits glucose production and glucagon secretion by the liver, and reduces appetite and food intake (Nauck et al. 1989; Kreymann et al. 1987; Trumper et al. 2001; Xu et al. 2006; Prigeon et al. 2003; Flint et al. 1998; Gutzwiller et al. 1999). For these reasons, drugs that increase GLP-1 activity have become attractive therapeutic options for patients with type 2 diabetes (Campbell and Miller 2009). GLP-1 receptor agonists (incretin or GLP-1 mimetics) and dipeptidyl peptidase-4 (DPP-4) inhibitors (CD26 antigen inhibitors) are the currently available incretin-based therapies proven to be safe and effective in the management of type 2 diabetes (Amori et al. 2007). However, they do not increase secretion of endogenous GLP-1, and therapies that directly

\footnotetext{
* Correspondence: t-horiuchi@toshima-hp.jp

${ }^{1}$ Division on Endocrinology and Metabolism, Tokyo Metropolitan Health

Medical Treatment Corporation Toshima Hospital, Itabashi, Japan

Full list of author information is available at the end of the article
}

target intestinal L cells to stimulate secretion of GLP-1 are expected to be effective.

Bile acids, the principal constituents of bile, along with cholesterol, phospholipids, and bilirubin, have been shown to stimulate GLP-1 secretion. GLP-1 levels were found to increase in the portal effluent, following the luminal perfusion of bile into perfused rat colon preparations (Plaisancie et al. 1995). Furthermore, bile acid sequestrants have been found to increase plasma GLP-1 levels in human and rodents (Chen et al. 2010; Shang et al. 2010; Garg et al. 2011; Suzuki et al. 2007). In addition, high concentrations of bile acids in direct contact with L-cell-rich regions of the intestine may contribute to the rapid remission of type 2 diabetes after gastric bypass surgery (Nakatani et al. 2009; Patti et al. 2009). Recently, a bile acid-sensitive G-protein-coupled receptor (GPCR), TGR5, was described (Maruyama et al. 2002), whose activation results in enhanced GLP-1 secretion (Katsuma et al. 2005; Thomas et al. 2009). In this study, we investigated whether ursodeoxycholic acid (UDCA), a widely used bile acid used therapeutically in liver diseases, induces GLP-1 secretion, and assessed its effects on glucose and insulin levels in healthy subjects.

\section{实}




\section{Results}

In this study, we examined 7 subjects ( 4 men and 3 women). The mean age of the patients was $33.4 \pm$ 7.8 years, and BMI was $20.4 \pm 2.4 \mathrm{~kg} / \mathrm{m}^{2}$. All the subjects were checked in the periodical health examination and checked for normal.

Mean changes in plasma glucose, serum IRI, and plasma active GLP-1 levels, with and without UDCA, are shown in Figure 1. A significant decrease in plasma glucose levels, comparing to UDCA intake, was observed at $30 \mathrm{~min}$ (without UDCA, $135 \pm 6 \mathrm{mg} / \mathrm{dl}$; with UDCA, $123 \pm 3.0 \mathrm{mg} / \mathrm{dl}, P=0.012$, Figure $1 \mathrm{~A})$. Serum IRI levels tended to increase after UDCA intake, but we found no statistically significant change at any time point (Figure 1B). However, plasma active GLP-1 levels were increased by UDCA intake. Significant increases were found at 60 , 90, and $180 \mathrm{~min}$ (Figure 1C). In addition, we examined AUCs to determine whether UDCA has a significant impact on metabolic parameters (Figure 2). We found a significant decrease in AUC of 0-60 min for plasma glucose (without UDCA, $7191 \pm 250 \mathrm{mg} \cdot \mathrm{min} / \mathrm{dl}$; with UDCA, $6716 \pm 189 \mathrm{mg} \cdot \mathrm{min} / \mathrm{dl}, P=0.001$; Figure 2A), but no significant change over 0-180 min (without UDCA, 19,074 $\pm 273 \mathrm{mg} \cdot \mathrm{min} / \mathrm{dl}$; with UDCA, 18,223 \pm $842 \mathrm{mg} \cdot \mathrm{min} / \mathrm{dl}, P=0.050$; Figure $2 \mathrm{~A})$. With respect to serum IRI, we found no significant increase in AUCs over 0-60 and 0-180 $\mathrm{min}$ (without UDCA, $1551 \pm 418$ $\mu \mathrm{U} \cdot \mathrm{min} / \mathrm{ml}$; with UDCA, $1941 \pm 246 \mu \mathrm{U} \cdot \mathrm{min} / \mathrm{ml}, P=$ 0.065 ; without UDCA, $3117 \pm 912 \mu \mathrm{U} \cdot \mathrm{min} / \mathrm{ml}$; with UDCA, $3590 \pm 794 \mu \mathrm{U} \cdot \mathrm{min} / \mathrm{ml}, P=0.165$, respectively; Figure 2B). Finally, we found a significant increase in plasma active GLP-1 levels at AUC of 0-60 min (without UDCA, $450 \pm 162 \mathrm{mmol} \cdot \mathrm{min} / \mathrm{l}$; with UDCA, $649 \pm$
$232 \mathrm{mmol} \cdot \mathrm{min} / \mathrm{l}, P=0.046$; Figure $2 \mathrm{C}$ ); however, over 0-180 $\mathrm{min}$, we found no significant change (without UDCA, $1230 \pm 485 \mathrm{mmol} \cdot \mathrm{min} / \mathrm{l}$; with UDCA, $1664 \pm$ $588 \mathrm{mmol} \cdot \mathrm{min} / \mathrm{l}, P=0.060$; Figure $2 \mathrm{C}$ ).

\section{Discussion}

To our knowledge, our study is the first to reveal a significant increase in postprandial plasma GLP-1 levels accompanied by a significant decrease in postprandial plasma glucose levels by UDCA intake in healthy subjects. We propose that these effects, increased GLP-1 and decreased glucose, explain, at least in part, the blood glucose-lowering action of UDCA, through increased plasma active GLP-1 levels resulting in higher serum insulin levels. Our data and recent findings on TGR5, which is a bile acid-sensitive GPCR (Maruyama et al. 2002) that enhances GLP-1 secretion (Katsuma et al. 2005; Thomas et al. 2009), suggest that UDCA stimulates GLP-1 secretion via TGR5 signaling. Furthermore, it was reported that a low carbohydrate/high-fat diet stimulates postprandial GLP-1 levels in healthy subjects (Numao et al. 2012). Because a high-fat diet elevates the fecal concentration of bile acids (Cummings et al. 1978; Bianchini et al. 1989), it is likely that bile acid induced by high-fat diet stimulates GLP-1 secretion. It follows that incretin hormones may stimulate insulin secretion through bile acids induced by fat diet, in addition to the widely known glucose-dependent pathway (Nauck et al. 1986).

In our study group, we observed a rapid transition of plasma glucose, serum IRI, and plasma active GLP-1 levels. The AUCs, which showed significant differences only over 0-60 min for plasma glucose and GLP-1,

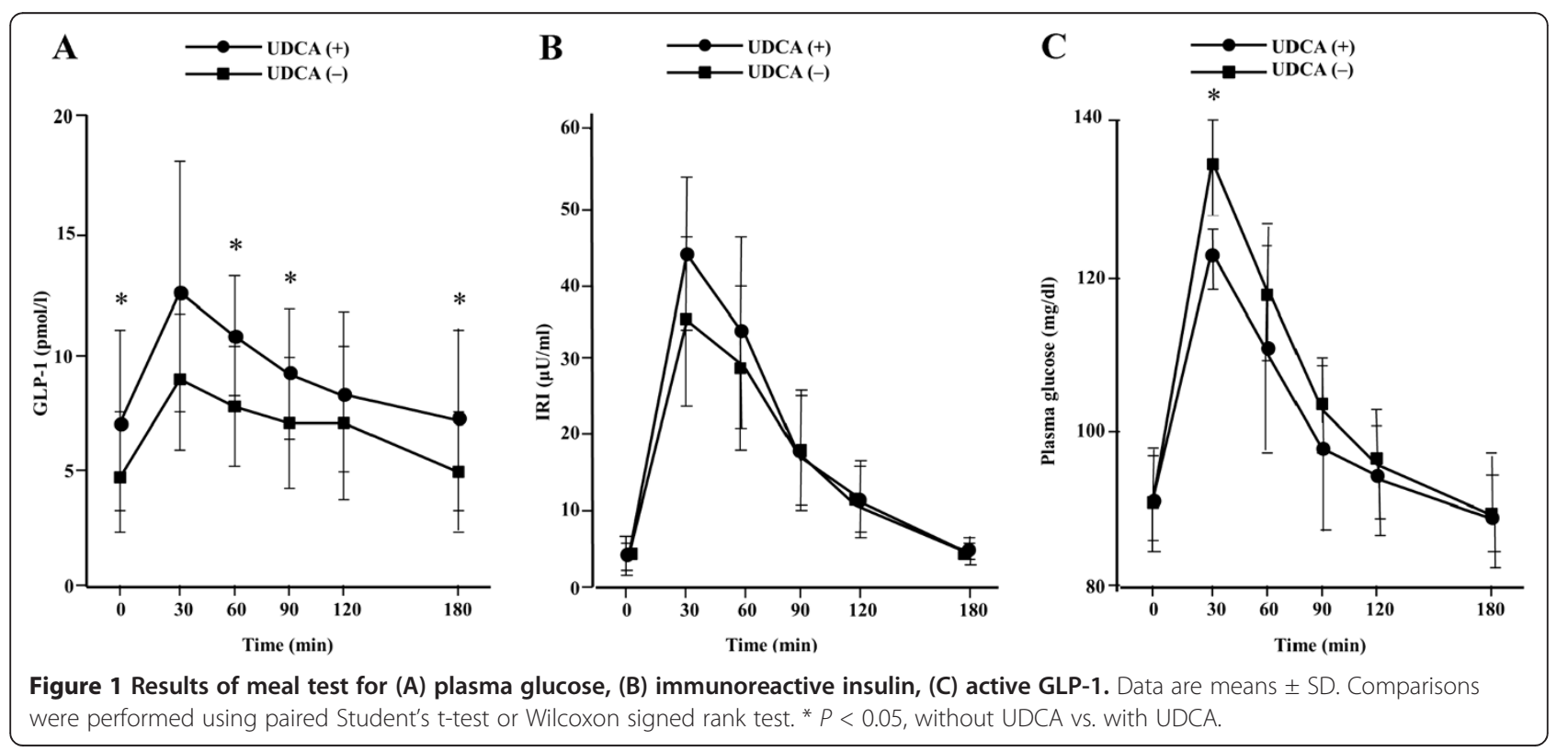



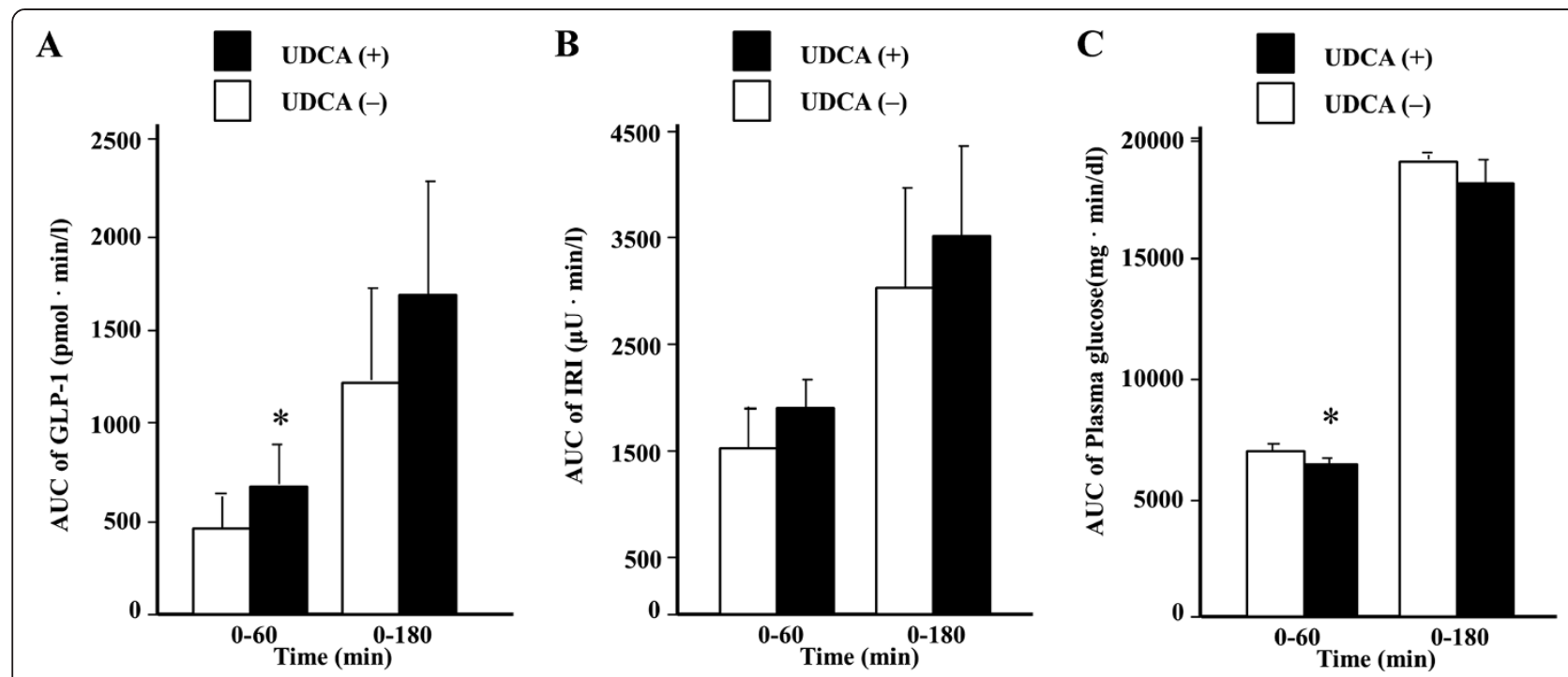

Figure 2 Results of meal test for AUC of (A) plasma glucose, (B) immunoreactive insulin, (C) active GLP-1. Data are means \pm SD. Comparisons were performed using paired Student's t-test or Wilcoxon signed rank test. ${ }^{*} P<0.05$, without UDCA vs. with UDCA.

suggest that UDCA works transiently in an early period after administration.

Incretin-based therapies such as GLP-1 receptor agonists and DPP-4 inhibitors are currently in use for the management of type 2 diabetes. However, these patients may retain GLP-1 secretion ability, which should be considered when planning treatment. UDCA is a candidate factor for evaluating GLP-1 secretion ability, because consumption of this drug increases plasma active GLP-1 secretion in healthy subjects, as indicated by our results. We evaluated the effect of UDCA only in healthy subjects; further study in type 2 diabetes patients is necessary to test this idea. Furthermore, UDCA is usually administered to patients with liver cirrhosis or chronic hepatitis, frequently suffering from abnormal glucose metabolism. It is possible that UDCA improves glucose intolerance in those patients. For example, nonalcoholic steatohepatitis patients treated with high-dose UDCA experienced significant reductions in serum glucose, glycosylated hemoglobin, and serum insulin levels (Ratziu et al. 2011).

Interestingly, there was no statistically significant difference in insulin secretion (Figures $1 \mathrm{~B}$ and $2 \mathrm{~B}$ ) induced by UDCA. A previous study showed that a high-fat diet, which induces bile acids secretion, stimulates GLP-1 secretion and lowers insulin levels transiently in the early phase (Numao et al. 2012). Thus, the effect of UDCA on insulin secretion should be evaluated on a finer time scale.

One limitation of our study is the small sample size. We studied only 7 subjects and the results varied widely. For example, statistically significant differences in plasma active GLP-1 levels were found unexpectedly at
0 min (without UDCA, $4.6 \pm 2.8 \mathrm{pmol} / \mathrm{l}$; with UDCA, $7.1 \pm 3.9 \mathrm{pmol} / \mathrm{l}, P=0.032$, Figure $1 \mathrm{C}$ ). Further study with a larger number of subjects is warranted.

\section{Conclusions}

In conclusion, UDCA increased GLP-1 secretion in healthy subjects. We propose that this drug may be useful as a tool for evaluating incretin secretion in type 2 diabetes mellitus.

\section{Methods}

\section{Subjects}

Seven people were recruited for this study. All subjects were non-obese (body mass index $(\mathrm{BMI})<25)$. Written informed consent was obtained from all participants with the approval of the ethics committee of Toshima Hospital.

\section{Meal tolerance tests}

Meal tolerance tests were performed after an overnight fast. The test meal was authorized by the Japan Diabetes Society; total caloric content of the meal was $460 \mathrm{kcal}$ (carbohydrates, $56.5 \mathrm{~g}$; protein, $18 \mathrm{~g}$; fat, $18 \mathrm{~g}$; JANEF E460F18, Q.P. Corporation, Tokyo, Japan). The test meal was ingested within $15 \mathrm{~min}$. Blood samples were collected at $0,30,60,90,120$, and $180 \mathrm{~min}$ after the meal. One week later, testing was performed again, with intake of UDCA $200 \mathrm{mg}$ (5\% granule, Urso, Mitsubishi Tokyo Pharmaceuticals) after the test meal.

Levels of glucose, immunoreactive insulin (IRI), and active GLP-1 in sera or plasma were measured at each time point. Plasma glucose concentrations were measured by the glucose oxidase method. IRI levels were 
measured with enzyme immunoassay kits. Plasma active GLP-1 samples were analyzed using ELISA (EGLP-35 K; Linco Research Inc., MO, USA). Plasma active GLP-1 concentrations were measured in plasma after addition of DPP-4 inhibitor (10 $\mu \mathrm{l} / \mathrm{ml}$ blood; Linco Research Inc., MO, USA).

\section{Statistical analysis}

Data are presented as means \pm standard deviation (SD). Statistical calculations including areas under the curve (AUCs) were carried out using paired Student's t-test or Wilcoxon signed rank test, as appropriate. A $P$ value $<$ 0.05 was taken to indicate a significant difference. Normality of the data was evaluated by the ShapiroWilk test.

\section{Competing interests}

The authors declare they have no competing interests in relation to this article.

\section{Authors' contributions}

All authors participated in the preparation of the manuscript, and read and approved the final manuscript.

\section{Acknowledgments}

We thank Drs Tatsuaki Goto, Ryuki Kawamura, Junnosuke Hayasaka, and Hiromi Matsuura (junior residents, Tokyo Metropolitan Health Medical Treatment Corporation Toshima Hospital) for data collection.

\section{Author details}

${ }^{1}$ Division on Endocrinology and Metabolism, Tokyo Metropolitan Health Medical Treatment Corporation Toshima Hospital, Itabashi, Japan. ${ }^{2}$ Tokyo Metropolitan Geriatric Hospital, Itabashi, Japan.

Received: 16 October 2012 Accepted: 13 January 2013

Published: 22 January 2013

\section{References}

Amori RE, Lau J, Pittas AG (2007) Efficacy and safety of incretin therapy in type 2 diabetes: systematic review and meta-analysis. JAMA 298:194-206

Bianchini F, Caderni G, Dolara P, Fantetti L, Kriebel D (1989) Effect of dietary fat, starch and cellulose on fecal bile acids in mice. J Nutr 119:1617-1624

Campbell RK, Miller S (2009) New therapeutic horizons: mapping the future of glycemic control with incretin-based therapy. Diabetes Educ 35:731-734, 738-740, 742-734 passim

Chen L, McNulty J, Anderson D, Liu Y, Nystrom C, Bullard S, Collins J, Handlon AL, Klein R, Grimes A, Murray D, Brown R, Krull D, Benson B, Kleymenova E, Remlinger K, Young A, Yao X (2010) Cholestyramine reverses hyperglycemia and enhances glucose-stimulated glucagon-like peptide 1 release in Zucker diabetic fatty rats. J Pharmacol Exp Ther 334:164-170

Cummings JH, Wiggins HS, Jenkins DJ, Houston H, Jivraj T, Drasar BS, Hill MJ (1978) Influence of diets high and low in animal fat on bowel habit, gastrointestinal transit time, fecal microflora, bile acid, and fat excretion. J Clin Invest 61:953-963

Flint A, Raben A, Astrup A, Holst JJ (1998) Glucagon-like peptide 1 promotes satiety and suppresses energy intake in humans. J Clin Invest 101:515-520

Garg SK, Ritchie PJ, Moser EG, Snell-Bergeon JK, Freson BJ, Hazenfield RM (2011) Effects of colesevelam on LDL-C, A1C and GLP-1 levels in patients with type 1 diabetes: a pilot randomized double-blind trial. Diabetes Obes Metab 13:137-143

Gutzwiller JP, Drewe J, Goke B, Schmidt H, Rohrer B, Lareida J, Beglinger C (1999) Glucagon-like peptide-1 promotes satiety and reduces food intake in patients with diabetes mellitus type 2. Am J Physiol 276:R1541-1544

Katsuma S, Hirasawa A, Tsujimoto G (2005) Bile acids promote glucagon-like peptide-1 secretion through TGR5 in a murine enteroendocrine cell line STC1. Biochem Biophys Res Commun 329:386-390
Kreymann B, Williams G, Ghatei MA, Bloom SR (1987) Glucagon-like peptide-1 736: a physiological incretin in man. Lancet 2:1300-1304

Maruyama T, Miyamoto Y, Nakamura T, Tamai Y, Okada H, Sugiyama E, Nakamura T, Itadani H, Tanaka K (2002) Identification of membrane-type receptor for bile acids (M-BAR). Biochem Biophys Res Commun 298:714-719

Nakatani H, Kasama K, Oshiro T, Watanabe M, Hirose H, Itoh H (2009) Serum bile acid along with plasma incretins and serum high-molecular weight adiponectin levels are increased after bariatric surgery. Metabolism 58:1400-1407

Nauck MA, Homberger E, Siegel EG, Allen RC, Eaton RP, Ebert R, Creutzfeldt W (1986) Incretin effects of increasing glucose loads in man calculated from venous insulin and C-peptide responses. J Clin Endocrinol Metab 63:492-498

Nauck M, Schmidt WE, Ebert R, Strietzel J, Cantor P, Hoffmann G, Creutzfeldt W (1989) Insulinotropic properties of synthetic human gastric inhibitory polypeptide in man: interactions with glucose, phenylalanine, and cholecystokinin-8. J Clin Endocrinol Metab 69:654-662

Numao S, Kawano H, Endo N, Yamada Y, Konishi M, Takahashi M, Sakamoto S (2012) Short-term low carbohydrate/high-fat diet intake increases postprandial plasma glucose and glucagon-like peptide-1 levels during an oral glucose tolerance test in healthy men. Eur J Clin Nutr 66:926-931

Patti ME, Houten SM, Bianco AC, Bernier R, Larsen PR, Holst JJ, Badman MK, Maratos-Flier E, Mun EC, Pihlajamaki J, Auwerx J, Goldfine AB (2009) Serum bile acids are higher in humans with prior gastric bypass: potential contribution to improved glucose and lipid metabolism. Obesity (Silver Spring) 17:1671-1677

Plaisancie P, Dumoulin V, Chayvialle JA, Cuber JC (1995) Luminal glucagon-like peptide-1(7-36) amide-releasing factors in the isolated vascularly perfused rat colon. J Endocrinol 145:521-526

Prigeon RL, Quddusi S, Paty B, D'Alessio DA (2003) Suppression of glucose production by GLP-1 independent of islet hormones: a novel extrapancreatic effect. Am J Physiol Endocrinol Metab 285:E701-E707

Ratziu V, de Ledinghen V, Oberti F, Mathurin P, Wartelle-Bladou C, Renou C, Sogni P, Maynard M, Larrey D, Serfaty L, Bonnefont-Rousselot D, Bastard JP, Riviere M, Spenard J, FRESGUN (2011) A randomized controlled trial of highdose ursodesoxycholic acid for nonalcoholic steatohepatitis. J Hepatol 54:1011-1019

Shang Q, Saumoy M, Holst JJ, Salen G, Xu G (2010) Colesevelam improves insulin resistance in a diet-induced obesity (F-DIO) rat model by increasing the release of GLP-1. Am J Physiol Gastrointest Liver Physiol 298:G419-G424

Suzuki T, Oba K, Igari Y, Matsumura N, Watanabe K, Futami-Suda S, Yasuoka H, Ouchi M, Suzuki K, Kigawa Y, Nakano H (2007) Colestimide lowers plasma glucose levels and increases plasma glucagon-like PEPTIDE-1 (7-36) levels in patients with type 2 diabetes mellitus complicated by hypercholesterolemia. J Nihon Med Sch 74:338-343

Thomas C, Gioiello A, Noriega L, Strehle A, Oury J, Rizzo G, Macchiarulo A, Yamamoto H, Mataki C, Pruzanski M, Pellicciari R, Auwerx J, Schoonjans K (2009) TGR5-mediated bile acid sensing controls glucose homeostasis. Cell Metab 10:167-177

Trumper A, Trumper K, Trusheim H, Arnold R, Goke B, Horsch D (2001) Glucosedependent insulinotropic polypeptide is a growth factor for beta (INS-1) cells by pleiotropic signaling. Mol Endocrinol 15:1559-1570

Xu G, Kaneto H, Lopez-Avalos MD, Weir GC, Bonner-Weir S (2006) GLP-1/exendin4 facilitates beta-cell neogenesis in rat and human pancreatic ducts. Diabetes Res Clin Pract 73:107-110

doi:10.1186/2193-1801-2-20

Cite this article as: Murakami et al:: Incretin secretion stimulated by ursodeoxycholic acid in healthy subjects. SpringerPlus 2013 2:20. 